\title{
Ecological and Health Risk Studies of Heavy Metals in Soils around an Abandoned Battery Factory in Ibadan, Southwestern Nigeria.
}

\author{
Romanus A. Obasi and Henry Y. Madukwe
}

\section{ABSTRACT}

Heavy metals on the soil around an abandoned battery site at Wofun, Ibadan, Southwestern, Nigeria were studied for their ecological and health risks. Ten soil samples collected from the soil around the abandoned battery sites were analyzed using Inductively Coupled Plasma -Mass spectrometry (ICP-MS). The data were evaluated using indices such as contamination factor, enrichment factor, geo-accumulation index and pollution index to determine the ecological and health risks posed by the heavy metals. The results showed an average concentration of $\mathrm{Pb}$ (7274.4), $\mathrm{V}$ (190.63), Cu (77.52), Zn (53.08) and Co (53) in a decreasing order. The enrichment factor revealed high enrichment for Co (12.30) at site one (S1), and extreme enrichment of $\mathrm{Pb}$ (61.12). $\mathrm{Zn}, \mathrm{Rb}$ and Mo showed no enrichment in the soil. All the sites exhibited extremely high enrichment of $\mathrm{Pb}$ except at $\mathrm{S10}$ where the enrichment of $\mathrm{Pb}$ was only severe. The results of Igeo indicated that all the sites were strongly to extremely polluted by $\mathrm{Pb}$ while $\mathrm{S6}$ is moderately polluted by $\mathrm{Co}$. The rest of the metals do not constitute any pollution threats. An evaluation of the ecological risk index (RI) revealed that the mean $\mathrm{Er}$ for $\mathrm{Co}(13.95), \mathrm{Cu}(\mathbf{8 . 6 1})$, and $\mathrm{Zn}(\mathbf{0 . 5 6})$ indicate low ecological risk as they are less than $40(\mathrm{Er}<40)$. Lead (Pb) with Er value of 1818.60 has a very high ecological risk and accounts for most of the ecological risks in the study area. Lead $(\mathrm{Pb})$ being the most toxic and abundant of all the heavy metals analyzed in the study areas was used to evaluate the potential non-carcinogenic health risk for both children and adults. The hazard index which is the sum of the hazard quotients for children is $\mathbf{2 6 . 6 4}$ suggesting that non-carcinogenic health risk may occur if there is any form of exposure to the soil. The hazard index for the adult (2.87) indicated a significant potential non-carcinogenic health risk in the study area.

Keywords: Ecological risk, hazard index, health risk, heavymetals, non-carcinogenic.

\section{INTRODUCTION}

Heavy metals are one of the most dangerous environmental sources of pollution in the world today. This is because soil is a repository of heavy metals and their concentrations vary in proportions. Some of these metals constitute good nutrients to the soil's plants while some others are nuisance to both the soil, plants and man. The soil has background concentrations of these metals and any metal concentration above the background should be investigated to determine the lethal levels, sources and deleterious effects on biota, including man. Many scholars have reported that exposure to some of these heavy metals can cause serious health problems such as hematological and brain damage, anaemia and kidney malfunctioning [1].

Reference [2] expressed that long exposure to lead causes
Published Online: July 12, 2020

ISSN: $2684-446 \mathrm{X}$

DOI : 10.24018/ejgeo.2020.1.4.8

\section{R. A. Obasi*}

Department of Geology, Ekiti State University, Ado Ekiti, Ekiti State Nigeria.

(e-mail: romanus.obasi@eksu.edu.ng)

H. Y. Madukwe

Department of Geology, Ekiti State University, Ado Ekiti, Ekiti State Nigeria.

(e-mail: henry.madukwe@eksu.edu.ng)

*Corresponding Author brain damage which may eventually lead to death. Cadmium has been found to cause renal dysfunction [3], excessive exposure to manganese is believed to have a negative impact on the central nervous system [4], while zinc toxicity is known to cause muscular stiffness and pain [5]. Wofun in Ibadan appears to be a potential risk area in view of the component properties of the abandoned battery sites. The evaluation of soils for heavy metals pollution has increased recently due to much emphasis on food security, national food sufficiency, self-reliance, and the potential health risks the heavy metals pose as well as adverse effects they have on the soil ecosystems and man [6]. It is this anticipated view that provoked the study, more so as little or no study has been done on the surrounding soil of the abandoned battery industry.

The present study tends to evaluate the ecological and 
health risks on the environment around the abandoned battery soils by studying the contamination and pollution levels using the pollution indices such as contamination factor (CF), geo-accumulation index (Igeo), and pollution load index (PLI) as well as potential ecological risk index (RI).

\section{MATERIALS AND METHODS}

\section{A. Study area}

The study area is located between longitudes $3^{\circ} 49^{\prime} \mathrm{E}$ and $3^{\circ} 57^{\circ} \mathrm{E}$ and latitudes $7^{\circ} 20^{\prime} \mathrm{N}$ and $7^{\circ} 27^{\prime} \mathrm{N}$ in the south-eastern part of Oyo State, South-western Nigeria. The studied area has a mean temperature range of $21.42^{\circ} \mathrm{C}-26.42^{\circ} \mathrm{C}$ yearly with average relative humidity of $74.55 \%$ and mean annual rainfall of approximately $1,420 \mathrm{~mm}$ with a vegetation of the tropical rainforest type. The general geology of the study area is that of the Pre-Cambrian rocks of Southwestern Nigeria where the major rock types are schist-quartzites, granite-gneiss, banded gneiss, augen-gneiss, and migmatites [7], and minor rock types such as pegmatite, aplites, quartz veins, and dolerite dykes intruded the main rocks in places (Fig.1). Gneisses are migmatized in places and are characterized by predominantly medium-sized grains while schist quartzites occur as elongated ridges striking NW-SE [8].

\section{B. Sample collection and preparations}

Ten (10) representative soil samples were collected from different areas around the abandoned battery site at Wofum Ibadan and its environs (Fig.2). The top soil samples were collected at regular distances from a depth of $30 \mathrm{~cm}$ using hand auger. These samples were put into the polythene bag, labelled and transported to the Ekiti State University, Department of Geology Engineering laboratory for sample preparations. The samples were then air dried, ground and sieved with $2 \mathrm{~mm}$ mesh to get a fine powder.

\section{Geochemical analysis}

The fine powdered samples are sent for geochemical analysis using Laser ablation microprobe Inductively Coupled Plasma -Mass Spectrometry (La ICP-MS) method at the Central Laboratory of the Stellenbosch University, South Africa. The ICP-MS instrument is a Perkin-Elmer Sciex ELAN 5100 coupled with a UV (266m) laser. Details of ICP-MS and laser operating conditions have been published by [9], [10]. Other methods employed include the use of geochemical indices such as enrichment factor, contamination factor, pollution load index and geoaccumulation index to determine the pollution levels of heavy metals in the soil around the abandoned battery sites and environs. The results of the geochemical analysis are presented in Table 1.

The concentration of Co ranged from 10.73 at S5 to $151.75 \mathrm{mg} / \mathrm{kg}$ at S6 with a mean value of $53.00 \mathrm{mg} / \mathrm{kg}$, Ni ranged from 18.35 at $\mathrm{S} 7$ to $71.90 \mathrm{mg} / \mathrm{kg}$ at $\mathrm{S} 8$ with a mean value of 35.90, $\mathrm{Cu}$ varied between 47.67 at $\mathrm{S} 10$ and 132.00 $\mathrm{mg} / \mathrm{kg}$ at $\mathrm{S} 6, \mathrm{~Pb}$ concentration ranged from 147.20 to $35600.00 \mathrm{mg} / \mathrm{kg}$ with a mean value of $7274.40 \mathrm{mg} / \mathrm{kg}$. The high concentration of $\mathrm{Pb}$ is attributed to the burning and dumping of battery in the area.

\section{EVALUATION OF CONTAMINATION LEVELS IN THE SOIL}

Different heavy metals were used to evaluate the degree of contamination and pollution levels in the soil with the purpose of determining the ecological risks and health risks imposed by them. In doing so, some contamination and pollution indices such as contamination factor (Cf), enrichment factor (Ef), geo-accumulation index (Igeo), ecological risk factor (Er) and health risks were used for the evaluation. Some of the qualitative thresholds used in the contamination indices are classified as reported in Table 2.

\section{A. Contamination Factor (CF)}

The contamination factor (CF) is used to calculate the contamination of a given toxic element/substance in a soil sample as shown in (1) and as given by [11]:

$$
\mathrm{C}_{\mathrm{F}}=\frac{\mathrm{C}_{\text {SAMPLE }}}{\mathrm{C}_{\text {BASELINE }}}
$$

Where $\mathrm{CF}-\mathrm{Contamination}$ factor

CSAMPLE - the concentration of element in soil sample CBASELINE - is the background value of element.

\section{B. Enrichment factor $(E F)$}

The enrichment factor (EF) is used to evaluate the level of contamination and their anthropogenic influence or otherwise on the soil of the abandoned battery site based on the measured element against reference element. To calculate the Ef, normalizing elements such as Al, Fe, Cs, Si are usually used and they should be characterized by low occurrence variability [12]-[15]. The normalizing element employed in this study is Cesium (Cs) due to its minimum variability of occurrence and low anthropogenic influence. The enrichment factor as given by [16] is defined by eq. (2):

$$
E_{\mathrm{F}}=\frac{\left(\mathrm{M} / \mathrm{N}^{\mathrm{ref}}\right)_{\text {SAMPLE }}}{\left(\mathrm{B} / \mathrm{N}^{\mathrm{ref}}\right)_{\text {BASELINE }}}
$$

Where $\mathrm{M}$ is the concentration of the element of interest and Nref sample is the concentration of reference element for normalization (Cs), $\mathrm{B}$ is the concentration of the element in the crust and Nref baseline is the concentration of the reference element used for normalization in the crust [17], [18]. Contamination categories defined for the enrichment factor are reported in Table 2 . 


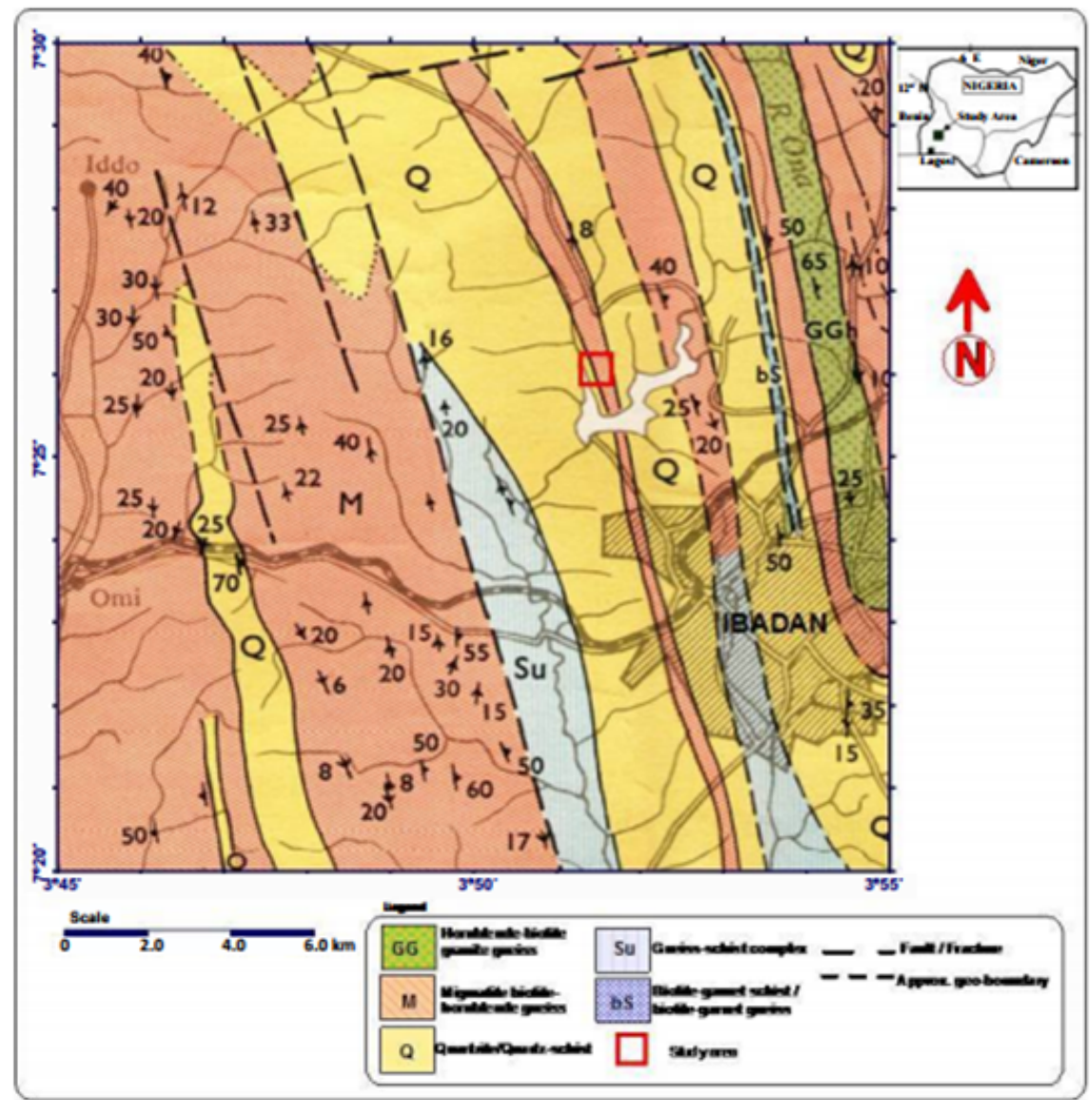

Fig.1. Geological Map of Ibadan showing the study area [19].

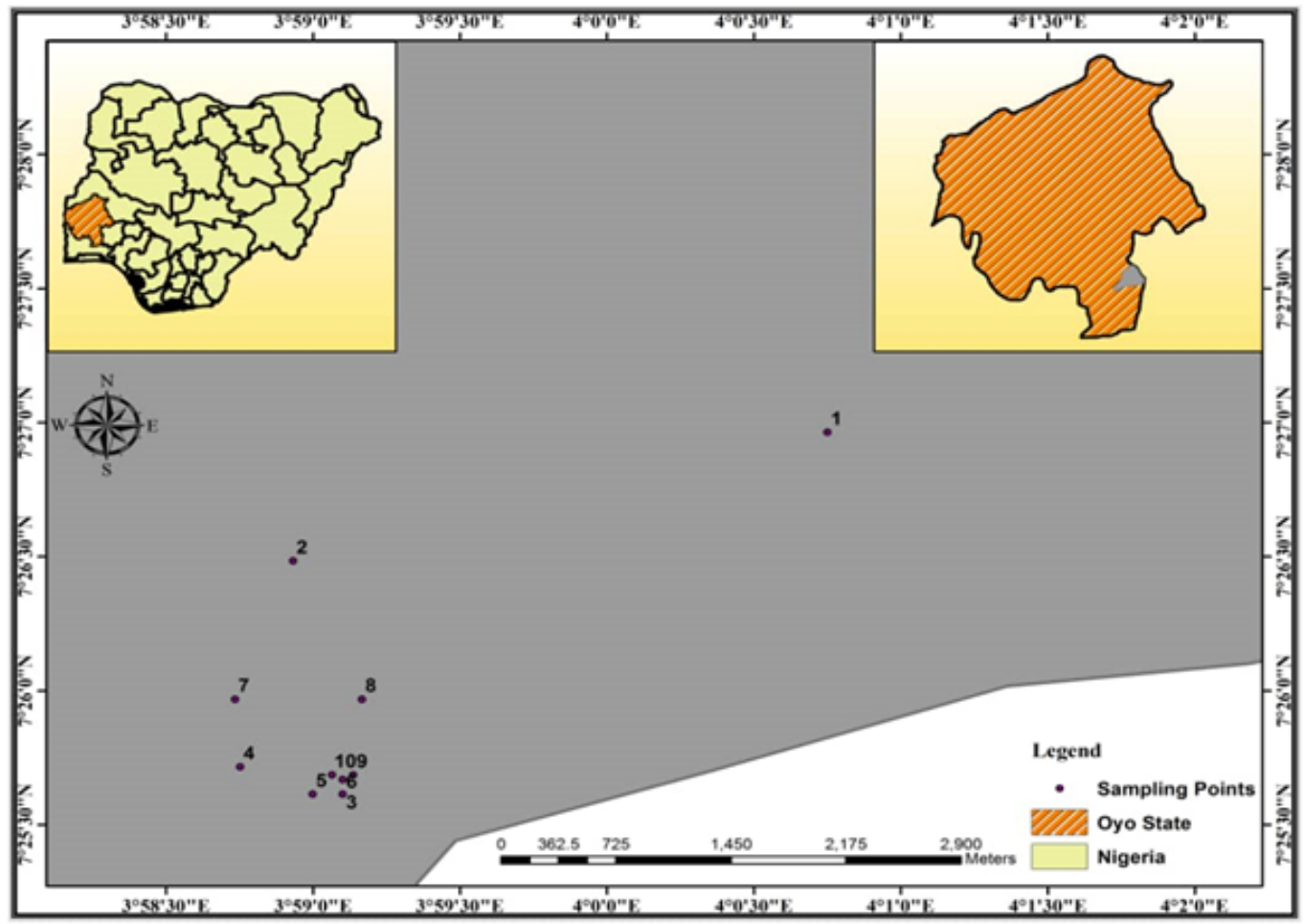

Fig. 2. Sampling points in the study area. 
TABLE 1: CONCENTRATION OF HEAVY METALS AROUND THE ABANDONED BATTERY

\begin{tabular}{ccccccccccc}
\multicolumn{10}{c}{$\mathrm{SITE}(\mathrm{MG} / \mathrm{KG})$} \\
\hline \hline Location & $\mathrm{Sc}$ & $\mathrm{V}$ & $\mathrm{Co}$ & $\mathrm{Ni}$ & $\mathrm{Cu}$ & $\mathrm{Zn}$ & $\mathrm{Rb}$ & $\mathrm{Mo}$ & $\mathrm{Cs}$ & $\mathrm{Pb}$ \\
\hline S1 & 21.81 & 220.6 & 72.54 & 32.2 & 80.35 & 42.85 & 41.47 & 0.76 & 1.55 & 379.3 \\
S2 & 23.34 & 220.9 & 70.4 & 29.95 & 99.85 & 69.65 & 37.41 & 1.03 & 2.1 & 23520 \\
S3 & 19.64 & 144.2 & 27.57 & 33 & 60.79 & 62.2 & 26.26 & 0.56 & 2.81 & 778.85 \\
S4 & 18.96 & 139.8 & 14.89 & 37.15 & 65.83 & 50.6 & 25.81 & 0.6 & 2.99 & 3550.5 \\
S5 & 19.07 & 125.2 & 10.73 & 20.25 & 50.18 & 33.55 & 26.53 & 0.57 & 1.95 & 2222.5 \\
S6 & 25.49 & 271.2 & 151.8 & 38.82 & 132 & 58.4 & 36.32 & 1.22 & 3.26 & 7.15 \\
S7 & 24.76 & 197.8 & 29.33 & 18.35 & 69.3 & 40.2 & 40.51 & 0.58 & 2.44 & 4717.5 \\
S8 & 20.63 & 155.2 & 21.96 & 71.9 & 62.14 & 58.85 & 16.9 & 0.95 & 5.12 & 979 \\
S9 & 21.68 & 221.1 & 56.62 & 39.15 & 107.1 & 74.7 & 35.15 & 1.29 & 3.79 & 35600 \\
S10 & 12.72 & 210.6 & 74.28 & 38.21 & 47.67 & 39.78 & 29.9 & 6.33 & 1.34 & 147.2 \\
Min & 12.72 & 125.2 & 10.73 & 18.35 & 47.67 & 33.55 & 16.9 & 0.56 & 1.34 & 147.2 \\
Max & 25.49 & 271.2 & 151.8 & 71.9 & 132 & 74.7 & 41.47 & 6.33 & 5.12 & 35600 \\
Mean & 20.81 & 190.6 & 53 & 35.9 & 77.52 & 53.08 & 31.62 & 1.39 & 2.74 & 7274.4 \\
SD & 3.64 & 47.09 & 42.57 & 14.65 & 27.3 & 13.83 & 7.83 & 1.76 & 1.14 & 12172.98 \\
\hline \hline
\end{tabular}

TABLE 2: CLASSIFICATION OF CONTAMINATION INDICES [11], [20], [21]

\begin{tabular}{|c|c|c|c|c|c|}
\hline $\begin{array}{l}\text { Enrichment Factor } \\
\text { (Ef) }\end{array}$ & Interpretation & $\begin{array}{l}\text { Pollution load Index } \\
\text { (PLI) }\end{array}$ & Interpretation & $\begin{array}{l}\text { Geo-accumulation } \\
\text { Index }\left(I_{\mathrm{geo}}\right)\end{array}$ & Interpretation \\
\hline $\mathrm{Ef} \leq 1$ & No enrichment & $\mathrm{PLI} \leq 1$ & no pollution & $I_{\mathrm{geo}} \leq 0$ & lass 0 - unpolluted \\
\hline $1-3$ & minimal & $(1<\mathrm{PLI}<2)$ & moderate pollution & $0<I_{\text {geo }} \leq 1$ & $\begin{array}{l}\text { class } 1 \text { - unpolluted to } \\
\text { moderately polluted }\end{array}$ \\
\hline $3-5$ & moderate & $(2<\mathrm{PLI}<3)$ & heavy pollution & $1<I_{\text {geo }} \leq 2$ & $\begin{array}{l}\text { class } 2 \text { - moderately } \\
\text { polluted }\end{array}$ \\
\hline $5-20$ & significant & $(3<\mathrm{PLI})$ & extremely heavy & $2<I_{\mathrm{geo}} \leq 3$ & $\begin{array}{l}\text { class } 3 \text { - from } \\
\text { moderately to } \\
\text { strongly polluted; }\end{array}$ \\
\hline $20-40$ & very high & & & $3<I_{\text {geo }} \leq 4$ & $\begin{array}{l}\text { class } 4 \text { - strongly } \\
\text { polluted }\end{array}$ \\
\hline $40-50$ & Severe & & & $4<I_{\text {geo }} \leq 5$ & $\begin{array}{l}\text { class } 5 \text { - from strongly } \\
\text { to extremely polluted }\end{array}$ \\
\hline$>50$ & extremely severe & & & $I_{\mathrm{geo}}>5$ & $\begin{array}{l}\text { class } 6 \text { - extremely } \\
\text { polluted }\end{array}$ \\
\hline
\end{tabular}

\section{Pollution load index (PLI)}

The PLI proposed by [22] determines the load and degree of pollution in the soil. This is expressed in (3) as:

$$
\mathrm{PLI}=\sqrt[n]{\sum_{i=1}^{n} C_{F 1} \times C_{F 2} \times C_{F 3} \times \ldots \times C_{F n}}
$$

where $\mathrm{n}$ is the number of metals and CF is the contamination factor. The pollution load index can be classified as: no pollution $(\mathrm{PLI}<1)$; moderate pollution $(1<\mathrm{PLI}<2)$; heavy pollution $(2<\mathrm{PLI}<3)$ and extremely heavy pollution $(3<\mathrm{PLI})$ Reference [23] classified each element as either low $(\mathrm{PLI}<1)$; middle $(1<\mathrm{PLI}<3)$ or high $(\mathrm{PLI}>3)$.

\section{Geo-Accumulation Index (I-Geo)}

Geo-accumulation index has been widely used to evaluate the degree of heavy metal contamination in terrestrial and aquatic environments as expressed in (4).

$I_{\text {geo }}=\log _{2}\left[\frac{C_{n}}{1.5 B_{n}}\right]$

Where $\mathrm{Cn}$ is the concentration of metal in the analyzed soil sample, $\mathrm{Bn}$ is the background concentration of metal and 1.5 is a factor for possible variation in the background concentration due to lithologic differences [24]. According to [25], geo-accumulation index (Igeo) is distinguished into seven classes (Table 2).

\section{DISCUSSION OF RESULTS}

The results of the contamination factor (CF) for the heavy metals are presented in Table 3 . The results show that Co ranges from 0.56 at $\mathrm{S} 5$ to $7.99 \mathrm{mg} / \mathrm{kg}$ at $\mathrm{S} 6$ with a mean value of $2.79 \mathrm{mg} / \mathrm{kg}, \mathrm{Cu}$ varies from 1.06 at site $\mathrm{S} 10$ to 2.93 $\mathrm{mg} / \mathrm{kg}$ at site $\mathrm{S} 6$, while $\mathrm{Pb}$ varies between 7.36 at $\mathrm{S} 10$ to $1780.00 \mathrm{mg} / \mathrm{kg}$ at S9 with a mean value of $363.72 \mathrm{mg} / \mathrm{kg}$. $\mathrm{Ni}, \mathrm{Zn}, \mathrm{Rb}$ and Mo have values that are less than one showing low contamination $(\mathrm{CF}<1)$. Sc, $\mathrm{Cu}, \mathrm{V}, \mathrm{CO}$ have values that are less than three $(1<\mathrm{CF}<3)$ thus indicating moderate contamination. $\mathrm{Pb}$ has lethal values that are greater than six $(\mathrm{CF}>6)$ showing high contamination and abundance in the area (7.36-1780.00) $\mathrm{mg} / \mathrm{kg}$.

\section{A. Enrichment factor}

Table 4 presents the results of enrichment factor (EF) of the heavy metals in the sampled soil at the different sites. Table 4 showed that site number one (S1) has high to extreme enrichment of $\mathrm{Co}$ (12.30) and $\mathrm{Pb}$ (61.12) respectively while sites $\mathrm{S} 6$ and $\mathrm{S} 10$ exhibited significant to extreme enrichment of $\mathrm{Co}$ and $\mathrm{Pb}$ respectively. Apart from $\mathrm{Zn}, \mathrm{Rb}$ and Mo which showed no enrichment in the soil, all the other metals show moderate enrichment in the soil. 
TABLE 3: CONTAMINATION FACTORS $\left(\mathrm{C}_{\mathrm{F}}\right)$

\begin{tabular}{cccccccccc}
\hline $\begin{array}{c}\text { Sample } \\
\text { ID }\end{array}$ & Sc & $\mathbf{V}$ & $\mathbf{C o}$ & $\mathbf{N i}$ & $\mathbf{C u}$ & $\mathbf{Z n}$ & $\mathbf{R b}$ & $\mathbf{M o}$ & $\mathbf{P b}$ \\
\hline S1 & 1.68 & 1.7 & 3.82 & 0.64 & 1.79 & 0.45 & 0.3 & 0.29 & 19 \\
S2 & 1.8 & 1.7 & 3.71 & 0.6 & 2.22 & 0.73 & 0.27 & 0.39 & 1176 \\
S3 & 1.51 & 1.11 & 1.45 & 0.66 & 1.35 & 0.65 & 0.19 & 0.22 & 38.9 \\
S4 & 1.46 & 1.08 & 0.78 & 0.74 & 1.46 & 0.53 & 0.18 & 0.23 & 178 \\
S5 & 1.47 & 0.96 & 0.56 & 0.4 & 1.12 & 0.35 & 0.19 & 0.22 & 111 \\
S6 & 1.96 & 2.09 & 7.99 & 0.78 & 2.93 & 0.61 & 0.26 & 0.47 & 42.5 \\
S7 & 1.9 & 1.52 & 1.54 & 0.37 & 1.54 & 0.42 & 0.29 & 0.22 & 236 \\
S8 & 1.59 & 1.19 & 1.16 & 1.44 & 1.38 & 0.62 & 0.12 & 0.37 & 49 \\
S9 & 1.67 & 1.7 & 2.98 & 0.78 & 2.38 & 0.79 & 0.25 & 0.49 & 1780 \\
S10 & 0.98 & 1.62 & 3.91 & 0.76 & 1.06 & 0.42 & 0.21 & 2.43 & 7.36 \\
Mean & 1.6 & 1.47 & 2.79 & 0.72 & 1.72 & 0.56 & 0.23 & 0.53 & 364 \\
\hline \hline
\end{tabular}

TABLE 4: ENRICHMENT FACTOR VALUES ( $\left.\mathrm{E}_{\mathrm{F}}\right)$

\begin{tabular}{cccccccccc}
\hline $\begin{array}{c}\text { Sample } \\
\text { ID }\end{array}$ & $\mathrm{Sc}$ & $\mathrm{V}$ & $\mathrm{Co}$ & $\mathrm{Ni}$ & $\mathrm{Cu}$ & $\mathrm{Zn}$ & $\mathrm{Rb}$ & $\mathrm{Mo}$ & $\mathrm{Pb}$ \\
\hline S1 & 5.41 & 5.47 & 12.3 & 2.08 & 5.75 & 1.45 & 0.95 & 0.94 & 61.1 \\
S2 & 4.27 & 4.04 & 8.81 & 1.42 & 5.28 & 1.74 & 0.64 & 0.94 & 2797 \\
S3 & 2.68 & 1.97 & 2.58 & 1.17 & 2.4 & 1.16 & 0.33 & 0.38 & 69.2 \\
S4 & 2.44 & 1.8 & 1.31 & 1.24 & 2.45 & 0.89 & 0.31 & 0.39 & 297 \\
S5 & 3.76 & 2.46 & 1.45 & 1.04 & 2.85 & 0.9 & 0.49 & 0.56 & 285 \\
S6 & 3.01 & 3.2 & 12.3 & 1.19 & 4.5 & 0.94 & 0.4 & 0.72 & 65.1 \\
S7 & 3.9 & 3.11 & 3.16 & 0.75 & 3.15 & 0.87 & 0.59 & 0.45 & 483 \\
S8 & 1.55 & 1.17 & 1.13 & 1.4 & 1.35 & 0.6 & 0.12 & 0.36 & 47.8 \\
S9 & 2.2 & 2.24 & 3.93 & 1.03 & 3.14 & 1.04 & 0.33 & 0.65 & 2346 \\
S10 & 3.65 & 6.04 & 14.6 & 2.85 & 3.95 & 1.56 & 0.8 & 9.08 & 27.5 \\
MEAN & 3.29 & 3.15 & 6.15 & 1.42 & 3.48 & 1.12 & 0.5 & 1.45 & 648 \\
SD & 1.13 & 1.6 & 5.28 & 0.61 & 1.38 & 0.36 & 0.25 & 2.69 & 1030 \\
\hline \hline
\end{tabular}

However, all the sites exhibited extreme enrichment of $\mathrm{Pb}$ except S10 where it was only severe. Reference [26] suggested that EF values close to 1 are indicative of crustal origins (naturally lithogenic) while Ef values greater than 10 are considered to be of non -crustal (anthropogenic) sources. The metal $\mathrm{Pb}$ (363.72) has values that are greater than 1 suggesting a potential anthropogenic source followed by Co and they are enriched in the soil. Heavy metals such as $\mathrm{Ni}$ (0.72), $\mathrm{Zn}(0.56)$, Mo (0.53) and Rb (0.23) have values that are less than 1, therefore, indicating the likelihood of an input from the natural crustal sources, hence minimum enrichments in the soil.

\section{B. Geo-accumulation Index (Igeo)}

The geo-accumulation index values are presented in Table 5 while the variations of the mean are illustrated in Figure. 3. These results indicated that all the sites were strongly to extremely polluted by $\mathrm{Pb}$ while $\mathrm{S} 6$ is moderately polluted by Co. All the other metals except $\mathrm{Sc}$ and $\mathrm{Cu}$ showed little or no pollution on the sites as shown in Fig. 3. Since there is no pollution of the areas by majority of the metals, it means that the areas are only affected by $\mathrm{Pb}$ which is as a result of the activities of the battery industry and their wastes. Reference [27] studied the battery waste dumpsite, at Ori-Ile Omilende area, Olodo, Ibadan, Nigeria and discovered that the concentration of lead, cadmium and iron were above the mean crustal concentrations. However, in the present study only $\mathrm{Pb}$ and $\mathrm{Co}$ can be said to be above the crustal values.

\section{Pollution Load Index (PLI)}

The pollution load index was used to determine the pollution load or quality of the soil within the study areas.

The results of pollution load index revealed that most of the sampling points are moderately polluted by heavy metals especially sampling points $\mathrm{S} 1, \mathrm{~S} 2, \mathrm{~S} 3, \mathrm{~S} 4, \mathrm{~S} 6, \mathrm{~S} 7, \mathrm{~S} 8$ and $\mathrm{S} 10$. The sites are moderately polluted because $\mathrm{Pb}$ is available in all the sites in proportions. The value of PLI at S5 (0.86) is less than one (PLI $<1)$ suggesting that the soil in that part of the study area is not polluted while PLI at S2 with 1.89 is less than two $(1<\mathrm{PLI}<2)$ and that at S9 with 2.15 is less than three $(2<\mathrm{PLI}<3)$, showing moderate to heavy pollution respectively (Fig.4). It is noted that the moderate pollution level at S6 may be due to the abundance of $\mathrm{Pb}$ in that area.

\section{Quotient of Contamination (QoC) (values in \%)}

Quotient of contamination is used to determine the degree of anthropogenic influence on heavy metal accumulation in the soil. When the (QoC) indicates 0 it implies that the concentration of the heavy metal in the soil is already at the pristine or background level and when it is negative it indicates that anthropogenic effect is less and the presence of the element is largely due to geogenic or natural geological processes, while a positive quotient of contamination suggests great anthropogenic influence of heavy metal accumulation. The result of the quotient of contamination (QoC) of each metal is reported in Table 6.

The result showed that $\mathrm{Ni}, \mathrm{Zn}, \mathrm{Rb}$, Mo and $\mathrm{Cs}$ from all the sampling sites were mostly negative (i.e below the background values) suggesting their derivation were mainly from geogenic sources. However, some of the metals are slightly above the background level and so have little evidence of anthropogenic impacts. Cobalt (Co) and lead $(\mathrm{Pb})$ have positive quotients of contamination suggesting a great anthropogenic influence of the heavy metal accumulation.

\section{E. Ecological Risk Index (Er)}

An ecological risk factor (Er) expresses the potential ecological risk of a given contaminant in the sediment /soil as suggested by [11] in (5).

$$
E_{R}=T_{R} \times C_{F}
$$

where $T_{R}$ is the toxic-response factor for a given substance and $\mathrm{C}_{\mathrm{F}}$ is the contamination factor.

Risk Index, $\mathrm{RI}=\mathrm{T}_{\mathrm{R}} \times \mathrm{C}_{\mathrm{F}}$

The terminology used to describe the risk factors and RI was suggested by [11], where: $\mathrm{Er}<40$ indicates a low potential ecological risk; $40<\mathrm{Er}<80$ is a moderate ecological risk; $80<\mathrm{Er}<160$ shows a considerable ecological risk; $160<\mathrm{Er}<320$ indicates a high ecological risk and $\mathrm{Er}>320$ indicates a very high ecological risk. In the case of risk index (6), $\mathrm{RI}<95$ indicates a low potential ecological risk; $95<\mathrm{RI}<190$ shows a moderate ecological risk; $190<\mathrm{RI}<380$ is a considerable ecological risk while $\mathrm{RI}$ $>380$ indicates a very high ecological risk. In order to determine the ecological risk index (Er) use is made of toxic response factors of 5,5, 1 and 5 for heavy metals $\mathrm{Co}, \mathrm{Cu}, \mathrm{Zn}$ and $\mathrm{Pb}[11]$ respectively. The results in Table 7 revealed that $\mathrm{Co}, \mathrm{Cu}$ and $\mathrm{Zn}$ with mean ecological risk 
Table 5: Geo-accumulation Index (Igeo)

\begin{tabular}{ccccccccccc}
\hline \hline Sample ID & $\mathrm{Sc}$ & $\mathrm{V}$ & $\mathrm{Co}$ & $\mathrm{Ni}$ & $\mathrm{Cu}$ & $\mathrm{Zn}$ & $\mathrm{Rb}$ & $\mathrm{Mo}$ & $\mathrm{Cs}$ & $\mathrm{Pb}$ \\
\hline $\mathrm{S} 1$ & 0.16 & 0.18 & 1.35 & -1.22 & 0.25 & -1.73 & -2.34 & -2.36 & -2.27 & 3.66 \\
$\mathrm{~S} 2$ & 0.26 & 0.18 & 1.3 & -1.32 & 0.56 & -1.03 & -2.49 & -1.93 & -1.83 & 9.61 \\
$\mathrm{~S} 3$ & 0.01 & -0.44 & -0.05 & -1.18 & -0.15 & -1.2 & -3 & -2.8 & -1.41 & 4.7 \\
S4 & -0.04 & -0.48 & -0.94 & -1.01 & -0.04 & -1.49 & -3.02 & -2.7 & -1.33 & 6.89 \\
S5 & -0.03 & -0.64 & -1.41 & -1.89 & -0.43 & -2.09 & -2.98 & -2.78 & -1.94 & 6.21 \\
S6 & 0.39 & 0.48 & 2.41 & -0.95 & 0.97 & -1.29 & -2.53 & -1.68 & -1.2 & 4.82 \\
S7 & 0.34 & 0.02 & 0.04 & -2.03 & 0.04 & -1.83 & -2.37 & -2.76 & -1.62 & 7.3 \\
S8 & 0.08 & -0.33 & -0.38 & -0.06 & -0.12 & -1.28 & -3.64 & -2.04 & -0.55 & 5.03 \\
S9 & 0.15 & 0.18 & 0.99 & -0.94 & 0.67 & -0.93 & -2.58 & -1.6 & -0.98 & 10.21 \\
S10 & -0.62 & 0.11 & 1.38 & -0.97 & -0.5 & -1.84 & -2.81 & 4.96 & -2.48 & 2.29 \\
MEAN & 0.07 & -0.07 & 0.47 & -1.16 & 0.13 & -1.47 & -2.78 & -1.57 & -1.56 & 6.07 \\
\hline \hline
\end{tabular}

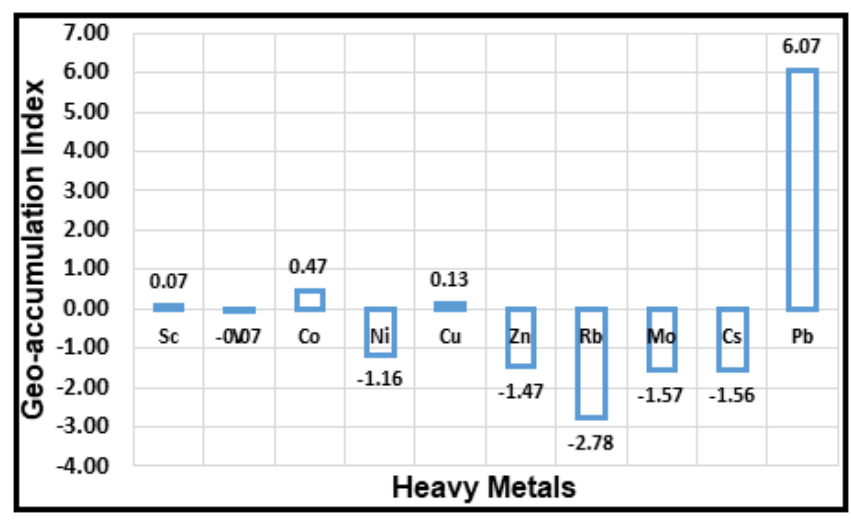

Fig.3. Concentration of Lead at sampling points in the Study Area.

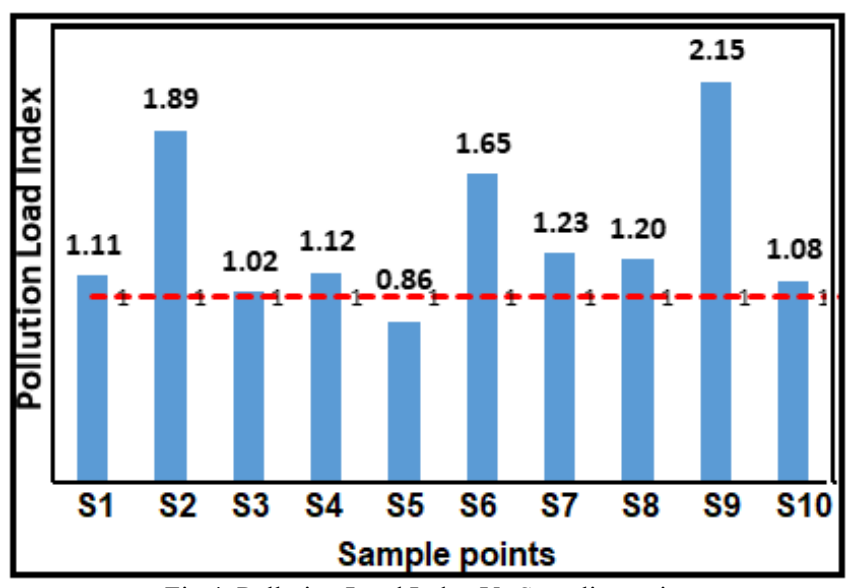

Fig.4. Pollution Load Index Vs Sampling point.

\begin{tabular}{ccccccccccc}
\multicolumn{1}{c}{ TABLE 6: QUANTIFICATION OF CONTAMINATION (QOC) (VALUES IN \%) } \\
\hline \hline Sample ID & $\mathrm{Sc}$ & $\mathrm{V}$ & $\mathrm{Co}$ & $\mathrm{Ni}$ & $\mathrm{Cu}$ & $\mathrm{Zn}$ & $\mathrm{Rb}$ & $\mathrm{Mo}$ & $\mathrm{Cs}$ & $\mathrm{Pb}$ \\
\hline $\mathrm{S} 1$ & 40 & 41 & 74 & -55 & 44 & -122 & -238 & -242 & -222 & 95 \\
S2 & 44 & 41 & 73 & -67 & 55 & -36 & -274 & -154 & -138 & 100 \\
$\mathrm{~S} 3$ & 34 & 10 & 31 & -52 & 26 & -53 & -433 & -364 & -78 & 97 \\
$\mathrm{~S} 4$ & 31 & 7 & -28 & -35 & 32 & -88 & -443 & -333 & -67 & 99 \\
S5 & 32 & -4 & -77 & -147 & 10 & -183 & -428 & -358 & -156 & 99 \\
S6 & 49 & 52 & 87 & -29 & 66 & -63 & -286 & -114 & -53 & 98 \\
S7 & 47 & 34 & 35 & -172 & 35 & -136 & -246 & -352 & -105 & 100 \\
S8 & 37 & 16 & 13 & 30 & 28 & -61 & -729 & -174 & 2 & 98 \\
S9 & 40 & 41 & 66 & -28 & 58 & -27 & -298 & -102 & -32 & 100 \\
S10 & -2 & 38 & 74 & -31 & 6 & -139 & -368 & 59 & -273 & 86 \\
\hline \hline
\end{tabular}

indices of $13.95,8.61$ and 0.56 , are less than $40(\mathrm{Er}<40)$ respectively all indicating low ecological risk. lead $(\mathrm{Pb})$ with ecological risk index value of $1818.60(\mathrm{Er}>320)$ is more than 320 and therefore pose a very high ecological risk. $\mathrm{Pb}$ accounts for most of the ecological risks in the study area as shown in Table 7.

\section{F. Potential Human Health Risk}

Health risks are assessed based on perceived polluted soil and the level of exposure and intake of the soil's products by man. What are assessed are non-carcinogenic and carcinogenic risks through two exposure pathways, incidental ingestion of the soil, and dermal contacts with the soil. Using the health risk assessment guidelines by [28], health risk can be identified in human activities. In these guidelines, the population has been divided into three groups; children, adults, and seniors and the exposure paths into two: dermal contact, and ingestion absorption route

In this study chronic daily intake (CDI, $\mathrm{mg} / \mathrm{kg} /$ day) is used for the evaluation of exposure to heavy metals in the soil. Reference [28] used (7) \& (8) to illustrate the exposure paths:

$$
\begin{aligned}
& C D I_{\text {INGESTION }}=\frac{C S \times I R \times C V \times F I \times E P \times E D}{B W \times A T} \\
& C D I_{D E R M A L}=\frac{C V \times C S \times S A \times A F \times A B S \times E P \times E D}{B W \times A T}
\end{aligned}
$$

where CS is the heavy metal concentration in the sediment $(\mathrm{mg} / \mathrm{kg})$; IR is the ingestion rate $(\mathrm{mg} /$ day); $\mathrm{CF}$ is the conversion factor $(\mathrm{kg} / \mathrm{mg})$; FI is the fraction ingested from the contaminated source (unit less); the EF of the CDIIngestion is the exposure frequency (days/year); ED is the exposure duration (years); BW is the average body weight $(\mathrm{kg})$; AT is the average time (days); SA is the exposed surface area of skin ( $\mathrm{cm} 2 /$ event); $\mathrm{AF}$ is the skin adherence factor $(\mathrm{mg} / \mathrm{cm} 2)$; ABS is the dermal absorption factor (unit less); EF of CDIDERmaL is the exposure frequency (events/year). The input parameters used for the calculation of CDI are given in Table 8.

\begin{tabular}{ccccc}
\multicolumn{5}{c}{ Table 7: Ecological risk index values. } \\
\hline \hline Sample ID & $\mathrm{Co}$ & $\mathrm{Cu}$ & $\mathrm{Zn}$ & $\mathrm{Pb}$ \\
\hline $\mathrm{S} 1$ & 19.09 & 8.93 & 0.45 & 94.83 \\
$\mathrm{~S} 2$ & 18.53 & 11.09 & 0.73 & 5880 \\
$\mathrm{~S} 3$ & 7.26 & 6.75 & 0.65 & 194.71 \\
$\mathrm{~S} 4$ & 3.92 & 7.31 & 0.53 & 887.63 \\
$\mathrm{~S} 5$ & 2.82 & 5.58 & 0.35 & 555.63 \\
$\mathrm{~S} 6$ & 39.93 & 14.67 & 0.61 & 212.29 \\
$\mathrm{~S} 7$ & 7.72 & 7.7 & 0.42 & 1179.38 \\
$\mathrm{~S} 8$ & 5.78 & 6.9 & 0.62 & 244.75 \\
S9 & 14.9 & 11.9 & 0.79 & 8900 \\
S10 & 19.55 & 5.3 & 0.42 & 36.8 \\
MEAN & 13.95 & 8.61 & 0.56 & 1818.6
\end{tabular}

Hazard index (HI) represents the sum of hazard quotients (HQ) that indicate the cumulative non-carcinogenic while HQ itself represents the ratio of the chronic daily intake (CDI) and the corresponding reference dose (Rf D). The Rf $\mathrm{D}$ values of $\mathrm{Co}, \mathrm{Ni}, \mathrm{Cu}, \mathrm{Zn}$, and $\mathrm{Pb}$ are $0.02,0.02,0.0371$, 0.3 , and $0.0035 \mathrm{mg} / \mathrm{kg} /$ day respectively [29]. A value of HI below 1 means no significant non-carcinogenic risk; a value 
of HI more than 1 indicates that an adverse noncarcinogenic risk effects may occur. HQ and HI are expressed in equations (9) and (10):

$$
\begin{aligned}
& H Q=\frac{C D I}{R f D} \\
& \mathrm{HI}=\sum H Q=H Q_{I N G E S T}+H Q_{D E R M A L}
\end{aligned}
$$

The non-carcinogenic health risk for lead $(\mathrm{Pb})$ was determined since lead is the most toxic and abundant of all the heavy metals analyzed in the soil of the study areas. This health risk index was determined for both children and adults. The CDI INGEST calculation for children indicated $0.093 \mathrm{mg} / \mathrm{kg} /$ day, while CDIDERMAL is $0.00026 \mathrm{mg} / \mathrm{kg} /$ day. The hazard quotients for dermal contact and ingestion were 0.074 and 26.57 respectively. The hazard index which is the sum of the hazard quotients is 26.64 and this suggests that non-carcinogenic health risk may occur if there is any form of exposure to the soil. The calculated CDI INGEST for adults is $0.01 \mathrm{mg} / \mathrm{kg} /$ day, while the CDIDERMAL is 0.0000398 $\mathrm{mg} / \mathrm{kg} /$ day. The hazard quotients for ingestion and dermal contact are 2.86 and 0.0114 respectively. The sum of the hazard quotients which is the hazard index is 2.87 , which also suggests that there is a significant non-carcinogenic health risk in the study area.

Table 8: The values of parameters used to estimate chronic daily

\begin{tabular}{cl}
\hline \multicolumn{1}{c}{ intake (CDI), after [28]. } \\
\hline \hline Parameter & \multicolumn{1}{c}{ Value } \\
\hline$I R$ & Child: $200 \mathrm{mg} /$ day; adult: $100 \mathrm{mg} /$ day \\
$C F$ & $1 \times 10^{-6} \mathrm{~kg} / \mathrm{mg}$ \\
$F I$ & 1 \\
$E F$ & 350 days/ year \\
$E D$ & Child: 6 years; adult: 30 years \\
$B W$ & Child: $15 \mathrm{~kg}$; adult: $70 \mathrm{~kg}$ \\
$A T$ & Non-carcinogenic: ED x 365 days/ years; \\
$S A$ & carcinogenic: 70 years x 365 days/ years \\
$A F$ & Child: $2800 \mathrm{~cm}^{2} ;$ adult: $5700 \mathrm{~cm}^{2}$ \\
$A B S$ & Child: $0.2 ;$ adult: 0.07 \\
$E F$ & 1 events/ day x 350 days/ year \\
\hline \hline
\end{tabular}

\section{CONCLUSION}

The results show that Co ranges from 0.56 at $\mathrm{S} 5$ to 7.99 $\mathrm{mg} / \mathrm{kg}$ at $\mathrm{S} 6$ with a mean value of $2.79 \mathrm{mg} / \mathrm{kg}, \mathrm{Cu}$ varies from 1.06 at site $\mathrm{S} 10$ to $2.93 \mathrm{mg} / \mathrm{kg}$ at site $\mathrm{S} 6$, while $\mathrm{Pb}$ varies between 7.36 at $\mathrm{S} 10$ to $1780.00 \mathrm{mg} / \mathrm{kg}$ at $\mathrm{S} 9$ with a mean value of $363.72 \mathrm{mg} / \mathrm{kg}$. The results of $\mathrm{Cf}$ of $\mathrm{Ni}, \mathrm{Zn}$, $\mathrm{Rb}$ and Mo indicated that their values are less than one $(\mathrm{CF}<$ 1) indicating low contamination. $\mathrm{Sc}, \mathrm{Cu}, \mathrm{V}, \mathrm{Co}$ have values that are greater than one but less than three $(1<\mathrm{CF}<3)$ showing moderate contamination. $\mathrm{Pb}$ has values that are greater than six $(\mathrm{CF}>6)$ implying that $\mathrm{Pb}$ poses high contamination in the study area (7.36-1780.00) $\mathrm{mg} / \mathrm{kg}$. The results of EF revealed high enrichment for Co (12.30) at site one (S1), and extreme enrichment of $\mathrm{Pb}$ (61.12). $\mathrm{Zn}, \mathrm{Rb}$ and Mo showed no enrichment in the soil except in S10 where the enrichment was moderate. All the sites exhibited extremely high enrichment of $\mathrm{Pb}$ except at $\mathrm{S} 10$ where the enrichment of $\mathrm{Pb}$ was only severe.

The results of Ef for the metals Co, (2.79), Cu (1.72),
SC ( 1.60), and $\mathrm{Pb}$ (363.72) indicated that their values are greater than 1.5 suggesting a potential anthropogenic source while heavy metals V (1.47), Ni (0.72), Zn (0.56), Mo (0.53) and $\mathrm{Rb}(0.23)$ have values that are less than 1.5 , indicating the likely input from the natural crust sources. The results of Igeo indicated that all the sites were strongly to extremely polluted by $\mathrm{Pb}$ while $\mathrm{S} 6$ is moderately polluted by $\mathrm{Co}$. The rest of the metals do not constitute any pollution except Sc and $\mathrm{Cu}$ which showed slight pollution on the sites. The result of risk index (RI) revealed that Er for heavy metals $\mathrm{Co}, \mathrm{Cu}$, and $\mathrm{Zn}$ with mean ecological risk values of 13.95 , 8.61 and 0.56 , are less than $40(\mathrm{Er}<40)$ respectively all indicating low ecological risk. Lead $(\mathrm{Pb})$ with ecological risk index value of $1818.60(\mathrm{Er}>320)$ is more than 320 and therefore has a very high ecological risk. $\mathrm{Pb}$ accounts for most of the ecological risks in the study area.

However, S10 showed light risk for being less than 40, S1 posed considerable ecological risk having been less than 160. Sites S3, S6 and S8 exhibited high ecological risk for their values are less than 320 while Sites S2, S4, S5, S7 and S9 are greater than 320 and therefore have very high ecological risks due to the presence of $\mathrm{Pb}$. Lead $(\mathrm{Pb})$ is the most toxic and abundant of all the heavy metals analyzed in the study areas, hence its use in the determination of the non-carcinogenic health risk. The health risk index was determined for both children and adults.

The results indicated that $\mathrm{CDI}_{\text {INGEST }}$ and CDI DERMAL for children are $0.093 \mathrm{mg} / \mathrm{kg} /$ day and $0.00026 \mathrm{mg} / \mathrm{kg} /$ day respectively. The hazard quotients for ingestion and dermal contacts were 26.57 and 0.074 respectively. The hazard index which is the sum of the hazard quotients is 26.64 suggesting that non-carcinogenic health risk may occur if there is any form of exposure to the soil. The CDI INGEST for adults is $0.01 \mathrm{mg} / \mathrm{kg} / \mathrm{day}$, while the CDIDERmal is 0.0000398 $\mathrm{mg} / \mathrm{kg} /$ day. The hazard quotients for ingestion and dermal contact are 2.86 and 0.0114 respectively. The sum of the hazard quotients which is the hazard index is 2.87, indicating that there is a significant non-carcinogenic health risk in the study area.

\section{ACKNOWLEDGMENT}

Special thanks go to my 2019/2020 project team who facilitated the collection of samples for this research.

\section{REFERENCES}

[1] Y. Sonayei, N. Ismail, and S. Talebi, "Determination of Heavy Metals of Industrial Effluent at Jaipur, Rajasthan India," Journal of Environment Science and Engineering, vol. 48, pp. 103-108, 2009.

[2] L. Simeonov, M. Kolhubovski, and B. Simeonov, Environmental heavy metal pollution and effects on child mental development, Dordrecht, Netherlands, Springer, 2010. pp. 114-115.

[3] R. Kumar, Nanostructured Oxides, Weinheim, Germany, Wiley VCN, 2009, pp. 166.

[4] M. Calkins, "Materials for Sustainable Sites: A Complete Guide to the Evaluation," Hoboken, New Jersey, John Wiley and Sons, 2009, p. 451.

[5] M. Al-Weher, "Levels of Heavy Metals $\mathrm{Cd}, \mathrm{Cu}$, and $\mathrm{Zn}$ in three fish species collected from the Northern Jordan Valley", Jordan Journal of Biological Sciences, vol. 1, pp. 41-46, 2008.

[6] A. Qishlaqi, and F. Moore, "Statistical Analysis of Accumulation and Sources of Heavy Metals Occurrence in Agricultural Soils of Khoshk River Banks, Shiraz, Lean," American-Eurasian Journal of Agriculture and Environment Science, vol. 2, pp. 565-573, 2007. 
[7] H. A, Jones, and R.D. Hockey, "The Geology of part of Southwestern, Nigeria,” Bull. Geol. Surv. Nigeria, vol. 31, pp. 101, 1964.

[8] M.O. Olorunfemi, J.S. Ojo, and O. Akintunde, Hydro-geophysical evaluation of the ground water potentials of the Akure metropolis, Southwestern Nigeria," Journal of Mining and geology, vol. 35, no. 2, pp. 207-228, 1999.

[9] M. D. Norman, N. J. Pearson, A. Sharma, and W. L. Griffin, "Quantitative analysis of trace elements in geological materials by laser by ablation ICPMS: instrumental operating conditions and calibration values of NIST glasses," Geostandards Newsletter, vol. 20, pp. 247-261, 1996.

[10] M. D. Norman, "Melting and metasomatism in the continental lithosphere: laser ablation ICPMS analyses of minerals in spinel, lherzolites from eastern Australia," Contributions to Mineralogy and Petrology, vol. 130, pp. 240- 255, 1998.

[11] L. Håkanson, "An ecological risk index for aquatic pollution control: A sediment ecological approach," Water Res., vol. 14, pp. 975-100, 1980.

[12] R.B. Khuzestani, and B. Souri, "Evaluation of heavy metal contamination hazards in nuisance dust particles in Kurdistan Province, Western Iran,” Journal of Environmental Science, vol. 25. No. 7, pp. 1346-1354, 2013.

[13] A. Reimann, and C. Caritat, "Distinguishing between natural and anthropogenic sources of element in the environment of regional geochemical surveys versus enrichment factors," Science of the total Enrichment, vol. 337, no. 1-3, pp. 91-107, 2005.

[14] E. Saur, and C. Juste, "Enrichment of trace elements from long range aerosol transport in Sandy podzolic soils of Southwest France," Water, Air and Soil pollution, vol. 73, pp. 235-245, 1994.

[15] R. A. Sutherland, "Bed sediment-associated trace metals in an urban stream, Oahu, Hawaii," Environmental Geology, vol. 39, no. 6, pp. 611-627, 2000.

[16] M. Ergin, C. Saydam, O. Basturk, E. Erdem, and R. Yoruk, "Heavy metal concentrations in surface sediments from the two coastal inlets (Golden Horn Estuary and_Izmit Bay) of the northeastern Sea of Marmara," Chem. Geol. Sci. vol. 91, pp. 269-285, 1991.

[17] A.F. Ato, O. Samuel, Y.D. Oscar, P. Alex, N. Moi, and B. Akoto, "Mining and heavy metal pollution: Assessment of aquatic environments in Tarkwa, Ghana using multivariate statistical analysis," Journal of Environmental Statistics, vol. 1, no. 4, 1-13, 2010.

[18] M.A. Oladunjoye, O.A. Sanuade, and A.A. Olaojo, "Variability of Soil Thermal Properties of a seasonally cultivated Agricultural Teaching and Research Farm, University of Ibadan, South-western Nigeria," Global Journal of Science Frontier Research Agriculture and Veterinary, vol. 13, no. 8, pp. 40-64, 2013.

[19] M.O. Olorunfemi, J.S. Ojo, and O. Akintunde, Hydro-geophysical evaluation of the ground water potentials of the Akure metropolis, Southwestern Nigeria," Journal of Mining and geology, vol. 35, no. 2, pp. 207-228, 1999

[20] S. A. Simex, and G.R. Helz, "Regional geochemistry of trace elements in Chesapeake Bay. Environ. Geo., vol. 3, pp. 315-323, 1981.

[21] USEPA, Principles of Environmental impact Assessment Review; Appendix A: Overview of the Environmental Impact Assessment Process, 1998.

[22] D.L. Tomlinson, J.G. Wilson, C.R. Harris, and D.W. Jeffrey, "Problems in the assessment of heavy metal level in estuaries and the formation of a pollution index," Helgol. Mar.Res., vol. 33, pp. 566575,1980

[23] T.B. Chen, Y.M. Zheng, M. Lei, Z.C. Huang, H.T. Wu, H. Chen, K. K. Fan, K. Yu, X. Wu, and Q. Z. Tian, "Assessment of heavy metal pollution in surface soils of urban parks in Beijing, China," Chemosphere, vol. 60, no, 4, pp. 542-551, 2005.

[24] H. Lokeshwari, and G.T. Chandrappa, "Impact of heavy metal contamination of Bellandur Lake on soil and cultivated vegetation," Current Science, vol. 91, pp. 622-627, 2006.

[25] G. Muller, "Dieschwermetall belstung der sediment des neckars und seiner nebenflusse: Eine estandsaufnahme, Chemiker Zeitung," vol. 105 , pp. 157-164, 1981.

[26] A.O. Afolayan, "Accumulation of Heavy Metal from Battery Waste in topsoil, Surface water, and Garden Grown Maize at Omilande Area," Olardo, Nigeria, pp. 43-53, 2018.

[27] USEPA, U.S. Environmental Protection Agency (EPA) Decontamination Research and Development Conference, U.S. Environmental Protection Agency, Washington, DC, EPA/600/R$11 / 052,2010$.
[28] USEPA. Integrated Risk Information System of the US Environmental Protection Agency; Office of Emergency and Remedial Response, Washington, DC, USA, 2012.

[29] USEPA, Principles of Environmental impact Assessment Review; Appendix A: Overview of the Environmental Impact Assessment Process, 1998. 